\title{
Air Quality Strategies and Technologies: A Rapid Review of the International Evidence
}

\author{
Sarah Quarmby ${ }^{1, *(\mathbb{D})}$, Georgina Santos ${ }^{2} \mathbb{0}$ and Megan Mathias ${ }^{3}$ \\ 1 Wales Centre for Public Policy, Cardiff University, Cardiff, Wales CF10 3BG, UK \\ 2 School of Geography and Planning, Cardiff University, Cardiff, Wales CF10 3WT, UK; santosg@cardiff.ac.uk \\ 3 States of Jersey, JE4 8QT, Jersey; M.Mathias@gov.je \\ * Correspondence: quarmbys@cardiff.ac.uk; Tel.: +44-(0)2922-510874
}

Received: 7 March 2019; Accepted: 6 May 2019; Published: 14 May 2019

check for updates

\begin{abstract}
Poor air quality is a pressing policy issue that spans public health and environmental portfolios, and governments worldwide are investing in a wide array of measures to address it. This paper is a rapid review of the evidence behind air quality strategies and technologies. It was conducted according to the principles of a systematic review, and includes both academic and "grey" literature sources. It focuses on road transport in urban areas, because air pollution tends to be worse in cities, and the main source is fossil fuel vehicles. It draws on the environmental science and policy literature to provide interdisciplinary insight into the most effective air quality policy measures. The most promising initiatives include active travel infrastructure, roadside barriers, low emission zones, and low speed limits. Technologies which remove pollution from the air largely remain unproven, especially at the scale needed to make a significant impact. The combinations of policies from three cities which rank highly for air quality are reviewed; one important finding is that policies are most effective when they are a part of a mutually reinforcing suite of measures. Policies consistent across the cities studied are good public transport coverage, a good cycle network, and financial incentives for electric vehicle purchase.
\end{abstract}

Keywords: air pollution; air quality; air pollution policies; electric vehicles; urban transport; behavioural change; public transport; active travel; emissions; private vehicles

\section{Introduction}

Poor air quality negatively affects human health and the environment. For this reason, governments and private sector organisations across the world are developing and trialling a wide range of ways to improve air quality. This paper provides a rapid review of the different types of air quality initiatives that exist internationally, and offers a brief indication of the evidence base behind them.

Epidemiological research has shown that poor air quality is a significant contributing factor to mortality and a range of cardiovascular and respiratory diseases [1,2]. It is estimated that 3-4 million people worldwide die each year due to exposure to $\mathrm{PM}_{2.5}$ [1], and in $2016,95 \%$ of people worldwide lived in areas where particulates exceeded the World Health Organisation's recommended levels [3]. This places poor air quality as a leading contributor to deaths worldwide, ahead of factors such as lack of exercise, poor sanitation and a low birth rate [3]. New research also suggests that the societal harm caused by poor air quality may be more subtle and pervasive than traditionally thought. Economic implications include decreased productivity, and exposure to poor air quality during early-life has been associated with decreased cognitive abilities later in life [2].

Policy decisions are at the core of issues of air quality, given that government actions spanning from pollution standards, to allocation of health resources and behaviour change approaches are key to influencing the level of harmful emissions in the air [1]. There is evidence from developing countries 
that government spending on air quality initiatives may not be proportional to their effectiveness, and that there is often an overemphasis on new technologies to the detriment of more mundane policy options, such as provisions for active travel [4].

In this paper, we locate air quality measures within the policymaking context by combining insights from the policy studies literature with the body of existing scientific knowledge on air quality. Given that local and national-level governments have the potential to play a significant role in helping reduce air pollution levels across the globe, air quality strategies and technologies that are most likely to have widespread impact are the ones that can be operationalised within respective policy contexts [5]. Air quality initiatives cannot be introduced in isolation from the policy context of which they are part. In addition, a greater understanding of the interface between science and policy will more effectively mobilise scientific knowledge for real-world impact [6-8].

Air quality measures are also unlikely to be effective in isolation given the complex and interacting factors that contribute to air pollution [9]. There is a disjuncture between the tendency in the scientific literature to study individual air quality interventions and the fact that social change is most often predicated on a combination of mutually reinforcing policy measures [10]. By providing empirical examples of the suite of policy measures enacted in three cities that rank highly for air quality, this paper builds on scientific research that has begun to address this issue, such as, for example [11,12]. It also includes an evaluation of initiatives that feature in the grey literature but do not yet feature in the academic literature, thus indicating promising avenues for further academic research.

Furthermore, it contributes to addressing the tendency in the scientific literature to focus overly on large, or "mega" cities, as in [13-15], whilst understudying smaller cities. Given that $31.9 \%$ of the world population live in cities of fewer than one million inhabitants (compared with $6.9 \%$ of the population which live in megacities of more than ten million inhabitants), the policy measures enacted in these smaller cities will reach a significant proportion of the world's population, and therefore have the potential for high impact [16].

Air quality is understood as the levels of pollutants in the air and how these compare with permissible levels [17]. The key air pollutants are: particulate matters $\left(\mathrm{PM}_{2.5}\right.$ and $\left.\mathrm{PM}_{10}\right)$, nitrogen oxides $\left(\mathrm{NO}_{\mathrm{X}}\right)$, sulphur dioxide $\left(\mathrm{SO}_{2}\right)$, carbon monoxide $(\mathrm{CO})$, and volatile organic compounds (VOCs). Table 1 summarises the sources of the different air pollutants and how these are formed.

Table 1. Air pollutants.

\begin{tabular}{|c|c|c|}
\hline Pollutant & Sources & More Information \\
\hline Nitrogen Oxides $\left(\mathrm{NO}_{\mathrm{x}}\right)$ & Transport and combustion. & $\begin{array}{l}\mathrm{NO}_{\mathrm{x}} \text { is the umbrella term for nitrogen } \\
\text { oxides most relevant to air pollution, } \\
\text { including nitrogen dioxide }\left(\mathrm{NO}_{2}\right) \text { and } \\
\text { nitric oxide (NO). }\end{array}$ \\
\hline Sulphur Dioxide $\left(\mathrm{SO}_{2}\right)$ & Transport and combustion (especially coal). & \\
\hline Carbon Monoxide (CO) & $\begin{array}{l}\text { Transport (especially petrol-based), } \\
\text { combustion and industry. }\end{array}$ & \\
\hline $\begin{array}{l}\text { Volatile Organic Compounds } \\
\text { (VOCs) }\end{array}$ & $\begin{array}{l}\text { Various, including transport } \\
\text { and combustion. }\end{array}$ & $\begin{array}{l}\text { VOCs are organic compounds which } \\
\text { evaporate easily and react with other } \\
\text { substances in the sunlight. }\end{array}$ \\
\hline
\end{tabular}

${ }^{1}$ Adapted from $[18,19]$.

The paper is structured as follows. In Section 2, we detail our research approach and the framework used for evaluating the evidence behind interventions. In Section 3, we provide an overview of the various strategies and technologies enacted internationally with the aim of improving air quality. 
In Section 4, we evaluate the combination of policy measures in three cities that rank highly for air quality. Finally, in Section 5, we conclude and suggest avenues for further research.

\section{Our Approach}

This paper presents a rapid literature review of both academic and "grey" literature. It was carried out according to the principles of a systematic literature search but does not aim to be a systematic review. A more detailed discussion of our search methodology is presented in the Appendix A, and the steps we followed are summarised in Figure 1.

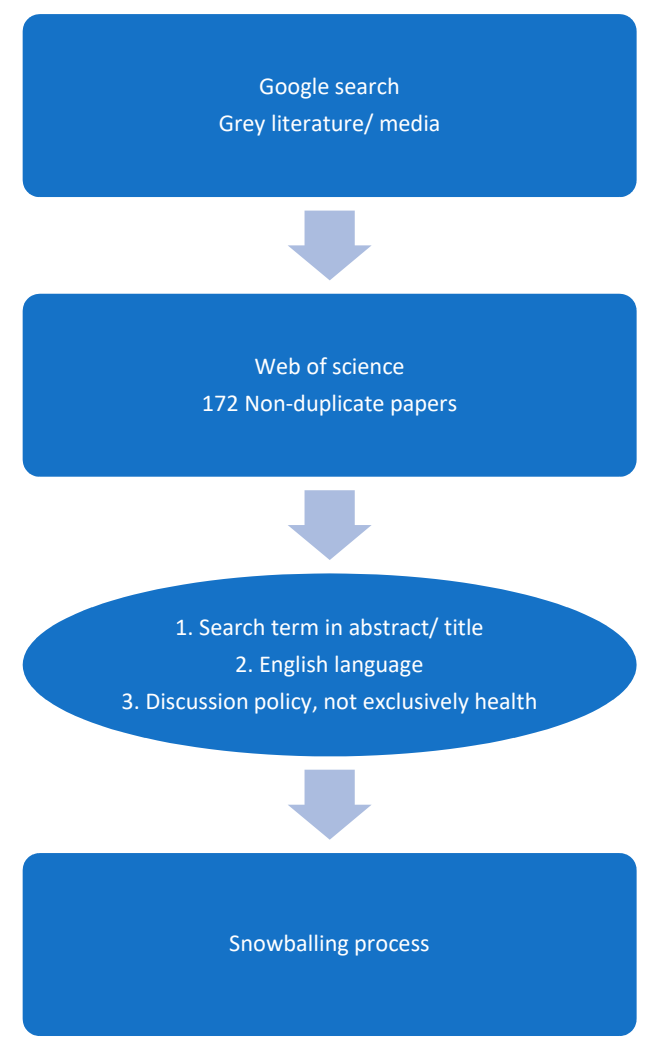

Figure 1. Diagram for Literature Search.

The main source of ambient air pollution is emissions from fossil fuel vehicles, and air pollution is generally worse in cities [20]. There is substantial research linking air pollution from traffic to negative health outcomes [12]. For these reasons, we focus on strategies and technologies relating to road transport in urban areas. The air quality impact of industrial and domestic pollutant sources tends to remain consistent or be improving over time, whilst traffic pollution problems are worsening across the world [21]; policies regarding industry and manufacturing are therefore not included in this study.

We divide air quality initiatives into strategies and technologies. Strategies encompass the policy levers available to governments, including legislation, "soft power", and taxation and funding. Technologies are subdivided into those which prevent emissions, and those which seek to retrospectively remove emissions from the air.

To assess the evidence-base for interventions, we use the following framework: evidence of effects (i.e., this has been shown to work), evidence of no effects (this has been shown to not work), and lack of evidence (there is insufficient evidence to determine whether this works or not) [22].

\section{Improving Air Quality: Individual Strategies and Technologies}

In this section, we review individual policy measures which aim to improve air quality, and indicate what evidence is available about their effectiveness. 


\subsection{Strategies}

The majority of air quality strategies for which evidence exists focus on discouraging private car use. This is predominantly done via regulations and legislation, as well as investing in infrastructure which promotes alternative transport. Here we discuss some key air quality strategies and offer illustrative examples where they have been put into practice.

\subsubsection{Low Emission Zones}

Low emission zones (LEZ) are areas in which vehicle use is restricted in order to limit tailpipe emissions. They are a popular localised air quality measure in European cities, with approximately 200 in existence across twelve European countries including, for example, England, Italy, Sweden, and Holland [23]. Restrictions typically apply to heavy duty vehicles, which usually run on diesel, but some LEZs also include other types of vehicles, such as very old, polluting cars. The zones are often created to ensure that cities comply with European emission standards, which have become more stringent over time, and so the types of vehicles which are allowed entry vary according to each location's needs.

London's low emission zone, which applies to most of the area within the M25 ring road and targets heavy duty diesel vehicles, is a prominent example and one of a number of area-specific air quality measures currently in place in the city. From April 2019 an Ultra Low Emission Zone will be introduced in the Congestion Charging area. This Ultra Low Emission Zone will include cars, motorcycles and vans, which will need to meet tighter emissions standards. In October 2021 the Ultra Low Emission Zone will be expanded to the inner London area, bounded by the North and South Circular roads [24].

There is some evidence that low emission zones can have a positive effect on air quality [25], although their efficacy varies dependent on the location's characteristics, as well as how stringent the zone's requirements are. For example, a study conducted in five Dutch cities found that low emission zones directed solely at heavy goods vehicles have no significant impact on air quality, suggesting that more wide-ranging restrictions achieve better air quality results [26].

A variation on low emission zones are zero emission zones, in which only cars that produce no tailpipe emissions, such as electric vehicles, are permitted. Oxford City Council recently set out plans to gradually move towards a zero-emission zone, starting in 2020 [27].

Congestion charging zones are an example of an associated initiative which is not primarily focused on air quality but may have effects thereupon. The cost of driving is increased via a congestion charge within a designated area or on certain roads, which acts as a deterrent for drivers. There is evidence that congestion charging assists a behavioural change shift from private car use to public transport [11], which may in turn improve air quality. An issue with low emission zones and congestion charging zones, like all measures focused on a particular area, is that emissions may be displaced rather than reduced overall and can result in poorer air quality outside the zone [28].

\subsubsection{Private Vehicle Behavioural Change}

Urban air quality policy combinations often ally methods for discouraging private car use with measures to make less polluting forms of transport, such as cycling and public transport, more appealing [29]. Investments in cycling and public transport infrastructure, such as a network of cycle lanes, are costly in the short term but may assist in facilitating long term behavioural change away from polluting transport. To ensure it is a viable option, public transport needs to be frequent, reliable, relatively quick and potentially, subsidised. Several countries are also considering ways to help people connect easily between different forms of transport. Singapore plans to create more integrated transport hubs, enabling easier transition between different modes of transport, for example, from bus to tram [29]. An integrated hub linking bus, train and cycling facilities opened in Port Talbot, Wales in 2017 [30] and a number of stations in London serve as underground, train and bus stations, and 
provide cycle racks, often inside the building. Examples include Paddington, Euston and King's Cross, to name a few.

Cycling is one of the least polluting transport modes, falling under the active travel category, along with walking [31]. Despite this, there is a lack of evidence quantifying the air quality impacts of cycling, since traffic related air quality research tends to focus on pollutant emissions produced. A recent study attempting to estimate air quality impacts from a number of walking and cycling schemes run by Sustrans, an active travel charity, in towns and cities in the UK, provides estimates of the air quality benefits for local populations due to reduced emissions from car journeys, and the impacts on an individual due to change in pollution exposure from shifting to active travel [32]. Although there was an improvement for local populations in some areas, the schemes did not have uniformly positive impacts and in some cases, such as Leeds, there was a negative effect. This is because the impacts of the schemes depend on the number of participants, the extent to which walkers and cyclists are exposed to air pollution, and the population density of the surrounding area, amongst others [32]. Furthermore, in areas where the majority of cycle routes are not separated from vehicle traffic, such as Cardiff and Plymouth, the schemes had a detrimental effect on people who use active travel [32].

Other studies, for example, estimate that a $40 \%$ reduction in car trips in Barcelona City would yield a reduction of $\mathrm{PM}_{2.5}$ concentrations of only $0.64 \%$, and 10.03 air pollution related deaths avoided per year [33]. They also find that the benefit for the general population due to reduced air pollution is much smaller than the benefit of the physical activity that cycling yields, a result also reported in [34]. Cycling initiatives, therefore, are a promising but not unproblematic air quality improvement strategy but must balance the potential negative side effects of cycling, such as the exposure of cyclists to vehicle emissions.

Increasing cycling effectively requires a network of dedicated cycle lanes with full coverage of a town or city, along with outreach campaigns to address issues related to safety perception. It is worth noting that the decision to cycle is influenced by many factors, including convenience [35,36], distance [37], safety perception [38,39], and weather conditions [40], amongst others. Simpler and less resource intensive initiatives include minor changes to existing infrastructure, such as ensuring that cyclists are permitted to take their bicycles onto trains and providing safe parking facilities at train stations [41]. These smaller measures are unlikely to individually have a measurable impact on air quality but may cumulatively assist in making an environment where cycling is a more appealing option.

Bicycle and car sharing schemes are also promising initiatives for improving air quality, and can be aided by technology, such as apps for car clubs [25,42]. They can also be encouraged by regulation or legislation. For example, in San Francisco employers are required to encourage cycling, car-pooling and public transport use by employees through subsidies or pre-tax deductions of transport costs [18]. Equally, the UK Government runs a "Cycle to Work" Scheme, in which employers can loan employees a bicycle tax free, sometimes in the form of a salary sacrifice arrangement [43].

\subsubsection{Speed Management}

Lower speed limits may be a cost-effective way of quickly making an impact on air quality near roads [44] and are included in several European countries' air quality plans [45]. For example, the Welsh Government has recently introduced $50 \mathrm{mph}$ speed limits on five main roads [46], and $20 \mathrm{mph}$ speed limits will be introduced on all TfL managed roads (approximately 5\%) in central London by 2020, although the measure is primarily aimed at improving road safety conditions [47]. The effect on emissions from lower speed limits is generally due to mitigating the stop-start nature of traffic, thus preventing unnecessary acceleration and deceleration, rather than the actual speed of the vehicles [11]. This includes pollution produced through brake and tyre wear, given that stopping from $20 \mathrm{mph}$ emits approximately half the amount of particulate matter from the brakes as stopping from $30 \mathrm{mph}$ [48]. The effects of speed management measures are dependent on local weather conditions and the physical infrastructure surrounding the road. For example, in Amsterdam, a speed limit 
reduction from approximately $62 \mathrm{mph}$ to $50 \mathrm{mph}$ resulted in decreased PM concentrations, but had no effect on NOx [49]. Speed management has in places been complemented by "eco-driving" campaigns, which educate the public on fuel-efficient forms of driving. An eco-driving programme carried out in the Netherlands between 1994 and 2004 is thought to have reduced fuel consumption by between 0.3 and $0.8 \%$ [50].

\subsubsection{Outreach Strategies}

Outreach and marketing activities have been shown to increase public awareness and compliance when used in conjunction with other air quality initiatives [25]. For example, Singapore's air quality strategy emphasises creating community ownership of air quality issues and holds annual 'community and youth for the environment' days. The Royal Borough of Kensington and Chelsea enlists 'green champions' to educate members of the community on energy efficiency and ways of reducing pollution [18]. Involving stakeholders from industry, academia and NGOs in designing and implementing interventions also leads to improved compliance, and can be facilitated through awards schemes, such as the City of London Corporation's awards for business which use sustainable technology [18].

On the other hand, the impetus for environmental ownership may arise from communities themselves, rather than local or national authorities. In 2017, residents of the Kings Heath suburb of Birmingham collaborated with the consultancy firm Earthsense to monitor local pollution levels, as well as organising a "Clean Air Day" where residents were encouraged to commute by active travel rather than private car [51]. The European Union also funded the CITI-SENSE project, in which approximately 400 volunteers were involved in establishing and monitoring an air quality sensor network of 324 individual units across Europe [52].

None of these community-led initiatives is likely to result in long-term impact by themselves. Whilst leaving the car at home may be feasible for everybody supporting the action one day, it may not be practical for all the other days of the year. Similarly, whilst neighbours may volunteer to help with air quality measurements for one day, it is unlikely that they would agree to do so to that extent on a regular basis. However, these community-led initiatives show that people in areas of high air pollution are aware of, and concerned by, the situation and may therefore be more likely to support policies introduced by the government.

\subsection{Technologies}

\subsubsection{Removing Pollutants from the Air}

Technologies designed to remove pollution from the air often gain media attention due to their unusual designs. For example, China has recently constructed a 100-m-tall air purifying tower in $\mathrm{Xi}^{\prime}$ an, which is shaped like a chimney and uses greenhouses to move air through a filtration system. There is however little evidence to substantiate the initial success claims made for the tower [53]. Separately, using substances which react with $\mathrm{NO}_{2}$ to absorb it from the air, have been trialled in several countries, including the Netherlands, Japan and England [54]. These can be applied to surfaces as paint or be integrated within materials themselves such as paving slabs and roofing felt. The results of these initiatives are as yet inconclusive, and everyday wear and tear can limit their effectiveness [54]. Delhi has also recently trialled water cannons to wash pollution out of the air, with no measurable effect [55]. Evidence is beginning to emerge that planting vegetation on surfaces of urban areas, for example, green walls and green roofs, has a small and highly localised positive impact on air quality [56,57].

The key problem with such initiatives is that only a small fraction of air ever comes into contact with any given technology, meaning that the overall impact on air quality is often negligible. Lewis urges caution regarding such initiatives and argues that "it is far, far easier to come up with technologies and 
schemes that stop harmful emissions at source, rather than try to capture the resulting pollution once it's free and in the air" [53].

\subsubsection{Switching to Less Polluting Cars}

A number of technologies exist to make diesel and petrol cars less polluting. Catalytic convertors, devices which make tailpipe emissions less harmful, have been a legal requirement for new vehicles in the UK and most other countries worldwide for several decades. The oil company Shell has developed a synthetic "drop in" alternative to diesel, i.e., one that requires no modification to the engine. This may have positive effects on NOx and PM emissions, but is yet to be rigorously evaluated [58]. Alternatively, San Paulo has focused on "flex" vehicles, which can run on different forms of fuel, usually a combination of petrol and ethanol [12]. Flex vehicles are different to hybrid vehicles, which are usually powered by both electric and fuel-burning engines. There is some evidence that ethanol-based flex vehicles may produce less NOx than petrol or diesel fuelled cars [59], but the specific context in Brazil, including their investment in ethanol production infrastructure [60], may mean that flex vehicles are a less viable initiative elsewhere.

Another common strategy is to encourage the population to substitute older, more polluting vehicles for newer, cleaner versions, which is most often achieved through a variety of taxation, subsidies and funding. Electric vehicles are the most high-profile cleaner car, and the proportion of the vehicle fleet made up by electric cars worldwide is increasing [61]. Electric vehicle uptake spans the strategies and technologies distinction, since this new technology can only make a positive impact on air quality if the population changes their buying behaviour and begins to use them. The majority of EU member states offer tax incentives or grants for buying and running electric vehicles [62]. On a smaller scale, San Paulo does not tax electric or hydrogen vehicle imports [12], and Southampton City Council used an Air Quality Grant from the UK Department for Environment, Food and Rural Affairs to fund cash-back for taxi drivers to replace polluting vehicles [63]. By contrast, cities around the world, including Mexico City, Athens, Paris and Madrid, plan to employ a legislative approach by banning diesel vehicles from city centres by 2025; and many countries have pledged to stop new petrol and diesel car sales by a set year, for example France and England by 2040 [64].

The International Energy Agency predicts that under the policies and measures that governments around the world have already put in place, the global stock of electric vehicles will reach 13 million by 2020 (up from 3.7 million in 2017) and nearly 130 million by 2030 [61]. Electric vehicles produce no tailpipe emissions whilst being driven, but consideration must be paid to how the electricity that powers them is generated, as well as whether they are charged in the daytime or at night [65]. Electric vehicles also still produce particulate matter resulting from tyre and brake wear and road abrasion. In the UK in 2015, the latest year for which statistics are available, $31 \%$ of $\mathrm{PM}_{10}$ emissions from road transport were from tailpipes, $45 \%$ were from tyre and brake wear, and $24 \%$ were from road abrasion [66].

In the longer term, there is a movement towards electric vehicles becoming autonomous, i.e., not requiring a human to drive them. Autonomous vehicles may have a positive impact on air quality by mitigating the human tendency for stop-start driving, as well as braking, and via vehicle platooning, where a number of vehicles travel closely together to improve aerodynamics [58]. A drawback of the increasing proportion of electric vehicles is that if numbers continue to grow as predicted, there may be the knock-on effect of reduced income from fuel duties for governments.

\subsubsection{Roadside Barriers}

Roadside noise reduction barriers, like congestion charging zones, have effects on air quality without this being their original purpose. Artificial barriers tend to lead to decreased pollution behind the barrier and are therefore regarded as a promising air quality measure [67,68]. Barriers comprised of a mixture of vegetation and artificial material seem to have the most positive impact on air quality, although barriers made solely of vegetation with thick foliage are also regarded as promising [69]. 


\subsubsection{Trees and Vegetation}

Perhaps counterintuitively, for the same reason that vegetation barriers can be effective in preventing the movement of pollution, trees can lead to reduced air quality within built-up urban environments. If they are planted along major roads, their canopies can act as a roof, preventing pollution from dissipating [70]. However, they can still be an effective way of improving air quality in less built-up environments $[56,69]$ and their leaves are capable of filtering out certain pollutants, such as $\mathrm{NO}_{2}$, from the air [70]. Guides regarding where to plant trees for optimal air quality benefit have been created, such as Morani et al.'s "planting priority index" map which ranks areas according to localised pollution levels, population density and existing tree cover [71]. There has also been research into the most effective tree species for improving air quality; conifers have been found to capture more pollution than broad leaved trees [72]. Initiatives focused on planting trees, such as New York's "Million Tree Initiative," therefore, may be beneficial, but should not be seen as the panacea for air quality issues [73].

There is some evidence that "urban greening" initiatives, such as green walls and vertical gardens can have a positive effect on air quality due to their capacity for trapping $\mathrm{NO}_{2}$ and particulate matter [74]. Sydney, Singapore and Mexico City are amongst the many cities worldwide to experiment in urban greening [75]. More research is needed to determine the effects of urban greening [76], but evidence suggests that urban form plays an important role in their effectiveness, for example, green walls may be most beneficial in "urban canyons", streets with high buildings along each side [74]. Consideration must also be given to upkeep costs and quantities of water required.

\subsubsection{Air Quality Monitoring}

Choosing the most effective air quality initiatives is predicated on knowing both the overall air pollution levels and the chemical composition of the pollution. Most countries, however, do not have a systematic approach to air quality monitoring. This results in a lack of air quality data, which undermines attempts to evaluate the effectiveness of air quality initiatives [29]. The need to expand and improve monitoring networks is consistently referenced in the literature as a fundamental prerequisite for improving air quality. Examples include $[17,29,77]$. As well as the EU funded CITI-sense network, and citizen-led monitoring mentioned above, attempts being made to address this include the Chinese government's creation of a nationwide network monitoring $\mathrm{PM}_{2.5}$ levels, the data from which is publicly available and can be checked in real time by anyone with a smartphone, much like the "LondonAir" app in England [78]. The potential for monitoring to improve air quality links to the broader interest in smart cities, a term used to denote the many and combined ways that technology can be incorporated into daily urban life to improve it [79].

\section{Improving Air Quality: City Case Studies}

In this section, we examine the policy initiatives of three cities which rank highly for air quality: Edinburgh (Scotland), Honolulu (Hawaii) and Tallinn (Estonia). We chose these three cities because they were among the cities with the lowest combined $\mathrm{PM}_{2.5}$ and $\mathrm{PM}_{10}$ concentrations, according to the World Health Organisation (WHO) Global Ambient Air Quality Database [20] and they had populations above 300,000 , so their relatively clean air could not be attributed to their small size. In addition, over $30 \%$ of the world population live in cities with fewer than one million inhabitants and so replicating interventions implemented in these smaller cities can potentially have far-reaching positive impact.

We focus on policies initiatives relating to road transport emissions, grouped into legislation and regulatory measures, "soft power" measures and financial incentives. This is by no means a comprehensive review of all policies targeting air pollution but aims to provide an overview of the types of initiatives generally employed by cities with good air quality. 


\subsection{Honolulu}

Honolulu is the capital of the US state of Hawaii, an island chain in the Central Pacific. As a US state, the overarching legislation governing air quality in the city is the US Federal Clean Air Act. Honolulu has an approximate population of 350,395 [80]. The city has an annual mean $\mathrm{PM}_{10}$ concentration of six micrograms per cubic meter of air $\left(\mu \mathrm{g} / \mathrm{m}^{3}\right)$ and a $\mathrm{PM}_{2.5}$ concentration of three $\mu \mathrm{g} / \mathrm{m}^{3}$ [20].

\subsubsection{Legislation/Regulation Measures}

Interestingly, Honolulu has relatively few regulations that prohibit polluting activities. There are no low or zero emission zones in the city, and no existing bans on diesel and petrol cars, although the state has pledged to eliminate fossil fuel use by ground transport by 2045 [81]. Nonetheless, Hawaii has low speed limits compared to other US states and European countries: $25 \mathrm{mph}$ in residential areas, $45 \mathrm{mph}$ on major roads in central Honolulu, and $55 \mathrm{mph}$ on most motorways. Leaving a car engine idling whilst stationary is also illegal, with a few exceptions [82], although it is not clear whether this restriction is enforced.

\subsubsection{Soft Power Measures}

Viable alternatives to private car use, such as good public transport and cycling provision, are key to encouraging less polluting behaviours. Honolulu has an extensive public transport network, with TheBus operating 104 routes across the city. Households defined as extremely low income are eligible for subsidised bus passes, and there is a free on-demand transport service for people with disabilities [83]. Oahu island, on which Honolulu is located, has 147 miles of cycle paths, and the Department of Transportation Services is currently updating the 2012 "O'ahu Bicycle Master Plan" with a focus on extending the network of cycle lanes, including protected bicycle lanes, where there is a physical barrier between the traffic and the cycle path [84]. A bicycle sharing scheme of 1000 bicycles at 100 stations was also introduced in 2017 [85].

\subsubsection{Financial Measures}

Hawaii has one of the highest fuel tax rates of US states with a petrol tax of 44.39 cents per gallon, and a diesel tax of 41.83 cents per gallon over and above the baseline federal tax. In the US the federal tax is 18.4 US cents per gallon for petrol and 24.4 US cents per gallon for diesel [86]. In addition, the different states can add a further tax, which in the case of Hawaii is 18.5 US cents per gallon for both petrol and diesel. Honolulu has another tax on top of the federal and state taxes of 16.5 US cents per gallon [87]. The total fuel tax paid by motorists in Honolulu is therefore 53.4 US cents per gallon for petrol and 59.4 US cents per gallon for diesel, or 12.1 and 13.5 euro cents per litre for petrol and diesel, respectively, using August 2018 exchange rates. This is higher than the average for the US, which is 46.7 and 53.7 US cents per gallon, or 10.6 and 12.2 euro cents per litre, respectively. Although the total tax paid by motorists in Honolulu is amongst the highest in the US, it is still low in relative terms given that the US has the lowest fuel duties of all OECD countries [88].

Hawaii has also encouraged electric vehicle purchase by offering federal tax credits of up to US\$7500 (equivalent to $€ 6451$ ) [89]. The state ranks second in the nation for electric vehicles per capita after California [81], and in 2017 had the fourth highest market share of electric vehicles [90].

\subsection{Tallinn}

Tallinn is the capital city of Estonia and has a population of approximately 450,531 [91]. Its particulate matter figures are $12 \mu \mathrm{g} / \mathrm{m}^{3}$ for $\mathrm{PM}_{10}$ and five $\mu \mathrm{g} / \mathrm{m}^{3}$ for $\mathrm{PM}_{2.5}$. Estonia is an $\mathrm{EU}$ member state, and therefore subject to EU air quality legislation. 


\subsubsection{Legislation/Regulation Measures}

Tallinn has few regulations relating to pollution from urban traffic. There are no low or zero emission zones in the city, no bans on diesel or petrol cars and no restricted idling times [92]. There are also no targeted speed management measures, with speed limits of approximately $31 \mathrm{mph}$ in built up areas and between 56 and $68 \mathrm{mph}$ on motorways [93].

\subsubsection{Soft Power Measures}

In 2013, public transport in Tallinn was made free at point of use, following a referendum in which the public voted in favour of the proposal. Registered Tallinn residents can purchase a personal "green card" for $€ 2$ which allows free access to the city's bus, tram, trolleybus and train network [94]. One year after introduction there was a $14 \%$ increase in the use of public transport, implying that the scheme has achieved its goal of increasing public transport usage. Conversely, an unanticipated effect of the scheme has been a decrease in walking in favour of public transport use [95]. According to the Head of the Tallinn European Union Office, the $€ 2$ green card scheme has generated an income surplus. As of 1 July 2018, every county in Estonia has the option of implementing free public transport, with the help of additional funding from the national government [96]. Tallin is not the only municipality to have established some form of free public transport, as similar schemes have existed in cities across the world with varying success [97]. The German government have announced plans to trial free public transport in five main cities by the end of 2018 in an effort to cut pollution levels to EU standards [64].

Tallinn also has a relatively extensive network of cycle paths and a small bicycle sharing scheme of approximately 100 bicycles [98]. However, an extremely low proportion (one per cent) of the population commute by bicycle [95]. The city's relatively poor weather conditions may be one of the factors influencing whether people decide to cycle.

\subsubsection{Financial Measures}

Estonia has a petrol tax of 56.3 euro cents per litre and a diesel tax of 49.3 euro cents per litre [99]. These taxes are roughly the averages for Europe, but well below the taxes that would internalise road transport externalities in Estonia, including air pollution from petrol and diesel [100].

Having sad that, between 2011 and 2014 the national government offered subsidies on electric vehicle purchase, up to a maximum of $€ 17,000$. There is general consensus that charging infrastructure is fundamental for electric vehicle market penetration [101]. The subsidies in Estonia were accompanied by setting up a network of 167 superfast charging stations, which take less than half an hour to recharge a car, in comparison with eight hours for most UK charging points, and at a distance of no more than $60 \mathrm{~km}$ apart. Between 2010 and 2015, Estonia was the EU member state with the second highest number of electric vehicle registrations as a share of total car registrations [102]. The number of electric cars purchased fell significantly when the scheme ended; only 43 electric vehicles were sold in 2017, equalling a market share of 0.17 per cent of GDP per capita [103]. The figures suggest that the scheme was both instrumental in encouraging electric vehicle uptake [104], but also did not establish enduring behavioural change regarding vehicle purchase choices.

\subsection{Edinburgh}

As the capital city of Scotland, Edinburgh is subject to EU air quality regulations, and like Wales, also falls under the UK Government Air Quality Strategy [105]. Despite low annual mean $\mathrm{PM}_{10}$ (nine $\mu \mathrm{g} / \mathrm{m}^{3}$ ) and $\mathrm{PM}_{2.5}\left(\mathrm{six} \mu \mathrm{g} / \mathrm{m}^{3}\right.$ ) concentrations [4], Edinburgh has suffered from high $\mathrm{NO}_{2}$ levels, with five $\mathrm{NO}_{2}$ related air quality management areas currently in operation in the city [106]. Edinburgh has an approximate population of 512,150 [107]. 


\subsubsection{Legislation/Regulation Measures}

There are no current restrictions on the circulation of petrol or diesel cars in the city, however, the Scottish Government has announced plans to introduce low emission zones in Edinburgh, Glasgow, Aberdeen and Dundee by 2020 [108]. This complements the government's commitment to phase out sales of new diesel and petrol cars by 2032 [109]. Speed management measures are employed, with $20 \mathrm{mph}$ speed limits introduced in phases since 2015 for residential roads, shopping streets and the city centre [110]. Idling times are also restricted according to Edinburgh Council's Air Quality Action Plan [111], although, similarly to Honolulu, it is unclear whether the restrictions are comprehensively enforced.

\subsubsection{Soft Power Measures}

Edinburgh has good public transport provision, with a network of buses in operation $24 \mathrm{~h}$ a day, along with 8.7miles of tram lines [112]. Public transport is paid for by the user, with the exceptions of those over 60 years old and certain people with disabilities who receive free bus passes [113]. The city also has a relatively extensive cycle path network, and $£ 12$ million funding has recently been dedicated for its extension [114]. A bicycle sharing scheme is scheduled for launch in September 2018 [115].

\subsubsection{Financial Measures}

In 2011, Transport Scotland launched a scheme of interest free loans for electric vehicle purchase of up to $£ 35,000$, and up to $£ 10,000$ for electric motorbikes or scooters, or $€ 38,889$ and $€ 11,111$ using August 2018 exchange rates. Although very few applications were made to the scheme during the first few years (just 18 loans were issued between 2012 and 2014), it is growing in popularity and there are plans for it to be expanded in 2019-2020 [116]. The fuel duty in the UK is one of the highest in Europe. The tax is the same for petrol and diesel, and since 2011, it has been 58 pence per litre [66], or 63.8 euro cents per litre.

\section{Conclusions and Policy Recommendations}

There is undisputable scientific evidence of the negative impacts of poor air quality on human health and the environment. In particular, epidemiological research has shown that air pollution has significant impacts on mortality and cardiovascular and respiratory diseases. Well-designed, effective policy interventions can substantially reduce air pollution.

This paper affords an overview of the strategies and technologies for tackling air pollution worldwide, with a focus on pollutants from road transport. It also examines the policies enacted by three cities that rank highly for air quality: Honolulu, Tallinn and Edinburgh. By focusing on real world examples of the policy portfolios implemented in three medium-size specific cities that rank highly for air quality, we contribute to both the scientific literature on the matter and to addressing the tendency of both the scientific and the "grey" literature to focus their attention on "mega" cities, where only under $7 \%$ of the world population lives, as opposed to medium size cities, where over $30 \%$ of the world population lives.

Our most important findings are as follows:

(a) A key way of improving urban air quality involves discouraging private use of petrol and diesel fuelled cars, and encouraging alternative forms of transport, including public transport, cycling, and electric vehicles, although electric vehicles will only reduce air pollution from tailpipe, not from tyre and break wear or road abrasion.

(b) The policy measures consistent across the three cities we concentrated on, Honolulu, Tallinn and Edinburgh, are: good public transport coverage, a good cycle network and financial incentives for electric vehicle purchase. 
(c) We also reviewed a number of additional policies, but there was a lack of consistency between the three cities, providing evidence for the intuitive claim that there are a wide variety of possible ways to achieve good air quality.

(d) A combination of complementary initiatives is key to creating impact in both the short and longer term. Initiatives with evidence of positive impacts on air quality in the short term include roadside barriers and speed management measures. In the longer term, behavioural change strategies to move people away from private car use are required.

(e) There is no convincing evidence that measures which retrospectively remove pollution from the air are effective in either the short or longer term.

In view of the above, the almost obvious policies that any city with air pollution levels above the limits recommended by WHO should implement include investing in public transport, to make it a reliable alternative, potentially offering subsidised fares, extending or updating a dedicated lane cycle network, separated from traffic, and with full coverage, and providing financial incentives for electric vehicles, preferably in combination with an extensive, reliable and fast charging network.

One limitation of the study is that although it is a review conducted in line with the principles of a systematic literature search, it is not a systematic review. We hope to expand this work into a major, systematic review, potentially combining it with a meta-analysis of the effectiveness of different interventions aimed at reducing air pollution.

Author Contributions: Conceptualization, M.M.; methodology, G.S.; validation, G.S. and M.M.; investigation, S.Q.; resources, G.S, M.M and S.Q; writing-original draft preparation, S.Q. and G.S.; writing-review and editing, S.Q., G.S. and M.M.

Funding: This research was funded by the Welsh Government, commissioned to the Wales Centre for Public Policy.

Conflicts of Interest: The authors declare no conflict of interest. The funders had no role in the design of the study; in the collection, analyses, or interpretation of data; in the writing of the manuscript, or in the decision to publish the results.

\section{Appendix A Literature Search Method}

Research for this report was conducted according to the principles of a systematic literature search, whilst not forming a systematic review. Both academic and "grey" literature sources (such as government and think-tank, trade press and professional associations' publications) were consulted. The initial database search was carried out during April 2018, and the "snowballing" process was carried out from May to August 2018.

The research process was as follows:

1. The Google search engine was used to identify relevant grey literature and media sources.

2. A search of the "web of science" database was conducted using the following search terms:

$$
\begin{aligned}
& \text { TS = ("air quality" AND technolog* AND "best practice" NOT indoor) } \\
& \text { TS = ("air quality" AND polic* AND "best practice" NOT indoor) } \\
& \text { TS = (international AND "air quality" AND polic* AND government* NOT indoor) } \\
& \text { TS = (international AND "air quality" AND polic* AND example* NOT indoor) } \\
& \text { TS = (international AND "air quality" AND polic* NOT indoor) } \\
& \text { TS = ("air pollution" near/3 technolog* NOT indoor) } \\
& \text { TS = ("air quality" near/5 technolog* NOT indoor) } \\
& \text { TS = ("air pollution" near/3 polic* NOT indoor) } \\
& \text { TS = ("air quality" near } / 3 \text { polic }{ }^{*} \text { NOT indoor) } \\
& \text { TS = ("air pollution" AND strateg* AND improve* NOT indoor) } \\
& \text { TS }=\text { ("air pollution" AND strateg* AND improve* NOT indoor) }
\end{aligned}
$$


3. Relevant articles were identified and saved to a reference management software. Articles were deemed relevant if they considered policies or technologies relating to emissions, air pollution, or air quality. Articles were considered not relevant if they discussed the health impacts of air pollution without consideration of policy responses, or if they focused exclusively on greenhouse gases. After duplicates were removed, there were 172 articles.

4. Abstracts were reviewed and the most relevant articles were identified and read in detail. A "snowballing" process followed as other relevant articles were identified from reference lists.

\section{References}

1. Heft-Neal, S.; Burney, J.; Bendavid, E.; Burke, M. Robust relationship between air quality and infant mortality in Africa. Nature 2018, 559, 254-258. [CrossRef]

2. Zivin, J.G.; Neidell, M. Air pollution's hidden impacts. Science 2018, 359, 39-40. [CrossRef]

3. Brainard, J. Risks of air pollution grow. Science 2018, 360, 360-361.

4. Deweerdt, S. The urban downshift. Nature 2016, 531, S52-S53. [CrossRef] [PubMed]

5. Stone, D. Transfer and translation of policy. Policy Stud. 2012, 33, 483-499. [CrossRef]

6. Hoppe, R. Rethinking the science-policy nexus: From knowledge utilization and science technology studies to types of boundary arrangements. Poiesis Prax. 2005, 3, 199-215. [CrossRef]

7. Wesselink, A.; Buchanan, K.S.; Georgiadou, Y.; Turnhout, E. Technical knowledge, discursive spaces and politics at the science-policy interface. Environ. Sci. Policy 2013, 30, 1-9. [CrossRef]

8. Young, J.C.; Waylen, K.A.; Sarkki, S.; Albon, S.; Bainbridge, I.; Balian, E.; Davidson, J.; Edwards, D.; Fairley, R.; Margerison, C.; et al. Improving the science-policy dialogue to meet the challenges of biodiversity conservation: Having conversations rather than talking at one-another. Biodivers. Conserv. 2014, 23, 387-404. [CrossRef]

9. Public Health England. Review of Interventions to Improve Outdoor Air Quality and Public Health. 2019. Available online: https://assets.publishing.service.gov.uk/government/uploads/system/uploads/attachment_ data/file/795185/Review_of_interventions_to_improve_air_quality.pdf (accessed on 25 April 2019).

10. Nilsson, M.; Griggs, D.; Visbeck, M. Map the interactions between Sustainable Development Goals. Nature 2016, 534, 320-322. [CrossRef]

11. Santos, G.; Behrendt, H.; Teytelboym, A. Part II: Policy instruments for sustainable road transport. Res. Transp. Econ. 2010, 28, 46-91. [CrossRef]

12. Slovic, A.; Ribiero, H. Policy instruments surrounding urban air quality: The cases of São Paulo, New York City and Paris. Environ. Sci. Policy 2018, 81, 1-9. [CrossRef]

13. Davis, L.W. The Effect of Driving Restrictions on Air Quality in Mexico City. J. Political Econ. 2008, 116, 38-81.

14. Parrish, D.D.; Zhu, T. Clean Air for Megacities. Science 2009, 326, 674-675. [CrossRef] [PubMed]

15. Mao, X.; Guo, X.; Chang, Y.; Peng, Y. Improving air quality in large cities by substituting natural gas for coal in China: Changing idea and incentive policy implications. Energy Policy 2005, 33, 307-318. [CrossRef]

16. United Nations. The World's Cities in 2018. 2018. Available online: http://www.un.org/en/events/citiesday/ assets/pdf/the_worlds_cities_in_2018_data_booklet.pdf (accessed on 1 April 2019).

17. Kuklinska, K.; Wolska, L.; Namiesnik, J. Air quality in the U.S. and the EU-A review. Atmos. Pollut. Res. 2016, 6, 129-137. [CrossRef]

18. Hesketh, R.; Jones, L.; Hinrichs-Krapels, S.; Kirk, A.; Johnson, S. Air Quality Improvement Initiatives in Other Cities: A Brief Review of Evidence to Inform Westminster City Council Air Quality Task Group; The Policy Institute, King's College London, UK; Westminster City Council: Westminster, UK, 2017.

19. Liu, Y.; Shao, M.; Fu, L.; Lu, S.; Zeng, L.; Tang, D. Source profiles of volatile organic compounds (VOCs) measured in China: Part 1. Atmos. Environ. 2008, 42, 6247-6260. [CrossRef]

20. WHO Global Ambient Air Quality Database. Available online: http://www.who.int/airpollution/data/cities/ en/ (accessed on 30 September 2018).

21. Causes of Air Pollution. Available online: https://uk-air.defra.gov.uk/air-pollution/causes (accessed on 30 September 2018).

22. Langer, L.; Tripey, J.; Gough, D. The Science of Using Science: Researching the Use of Research Evidence in Decision-Making; EPPI-Centre, Social Science Research Unit, UCL Institute of Education, University College London: London, UK, 2016. 
23. Holman, C.; Harrison, R.; Querol, X. Review of the efficacy of low emission zones to improve urban air quality in European Cities. Atmos. Environ. 2015, 111, 161-169. [CrossRef]

24. Low Emission Zone. Available online: https://tfl.gov.uk/modes/driving/low-emission-zone (accessed on 30 November 2018).

25. Bigazzi, A.Y.; Rouleau, M. Can traffic management strategies improve urban air quality? A review of the evidence. J. Transp. Health 2017, 7, 111-124. [CrossRef]

26. Boogaard, H.; Janssen, N.A.H.; Fischer, P.H.; Kos, G.P.A.; Weijers, E.P.; Cassee, F.R.; van der Zee, S.C.; de Hartog, J.J.; Meliefste, K.; Brunekreef, B.; et al. Impact of low emission zones and local traffic policies on ambient air pollution concentrations. Sci. Total Environ. 2012, 435-436, 132-140. [CrossRef]

27. Oxford Zero Emission Zone (ZEZ). Available online: https://www.oxford.gov.uk/zez (accessed on 6 March 2019).

28. Hawkes, N. Air pollution in the UK: The public health problem that won't go away. BMJ 2015, 350, h2757. [CrossRef]

29. Actions on Air Quality: Policies and Programmes for Improving Air Quality around the World. Available online: http://ccacoalition.org/sites/default/files/resources/AQ_GlobalReport_Summary.pdf (accessed on 9 September 2018).

30. Port Talbot’s New £5.6M Integrated Transport Hub Opens. Available online: https://businessnewswales. com/port-talbots-new-5-6m-integrated-transport-hub-opens/ (accessed on 10 September 2018).

31. Working Together to Promote Active Travel: A Briefing for Local Authorities. Available online: https://assets.publishing.service.gov.uk/government/uploads/system/uploads/attachment_data/file/ 523460/Working_Together_to_Promote_Active_Travel_A_briefing_for_local_authorities.pdf (accessed on 30 September 2018).

32. Air Quality Benefits of Active Travel, Final Report for Sustrans. Available online: http://www.eunomia.co. uk/report-category/client/sustrans/ (accessed on 31 August 2018).

33. Rojas-Rueda, D.; de Nazelle, A.; Teixido, O.; Nieuwenhuijsen, M. Replacing car trips by increasing bike and public transport in the greater Barcelona metropolitan area: A health impact assessment study. Environ. Int. 2012, 49, 100-109. [CrossRef] [PubMed]

34. Rabl, A.; de Nazelle, A. Benefits of shift from car to active transport. Transp. Policy 2012, 19, 121-131. [CrossRef]

35. Bopp, M.; Kaczynski, A.; Besenyi, G. Active commuting influence among adults. Prev. Med. 2012, 54, $237-241$. [CrossRef] [PubMed]

36. Mackett, R. Why do people use their cars for short trips? Transportation 2003, 30, 329-349. [CrossRef]

37. Scheiner, J. Interrelations between travel mode choice and trip distance: Trends in Germany 1976-2002. J. Transp. Geogr. 2010, 18, 75-84. [CrossRef]

38. Bonham, J.; Koth, B. Universities and the cycling culture. Transport and Research Part D: Transp. Environ. 2010, 15, 94-102. [CrossRef]

39. Wang, T.; Mirza, L.; Cheung, L.; Moradi, S. Understanding factors influencing choices of cyclists and potential cyclists: A case study at the University of Auckland. Road Transp. Res. J. Aust. N. Z. Res. Pract. 2014, 23, 37-51.

40. Sabir, M. Weather and Travel Behaviour. Ph.D. Thesis, Department of Spatial Economics, Faculty of Economics and Business Administration, Vrije Universiteit Amsterdam, Amsterdam, The Netherlands, 2011. Available online: https://research.vu.nl/en/publications/weather-and-travel-behaviour (accessed on 2 September 2018).

41. Rietveld, P. The accessibility of railway stations: The role of the bicycle in The Netherlands. Transp. Res. Part D Transp. Environ. 2000, 5, 71-75. [CrossRef]

42. Toxic Emissions Down, but People Still Dying from Air Pollution-It's Time for Something Radical. Available online: https://theconversation.com/toxic-emissions-down-but-people-still-dying-from-air-pollution-itstime-for-something-radical-91875 (accessed on 18 September 2018).

43. Department for Transport. Cycle to Work Scheme Implementation Guidance for Employers. 2011. Available online: https://www.gov.uk/government/publications/cycle-to-work-scheme-implementation-guidance (accessed on 8 September 2018). 
44. Porter, C.; Kall, D.; Selin, T.; Baker, R.; Kishan, S.; Preusse, D.; Stanard, A. Evaluate the Interactions between Transportation-Related Particulate Matter, Ozone, Air Toxics, Climate Change, and Other Air-Pollutant Control Strategies; NCHRP No. 25-25, Task 59; Transportation Research Board: Washington, DC, USA, 2010.

45. D'Elia, I.; Piersanti, A.; Briganti, G.; Cappelletti, A.; Ciancarella, L.; Peschi, E. Evaluation of mitigation measures for air quality in Italy in 2020 and 2030. Atmos. Pollut. Res. 2018, 9, 977-988. [CrossRef]

46. $£ 20 \mathrm{M}$ Air Quality Fund among New Measures to Improve Air Quality in Wales. Available online: https://gov.wales/newsroom/environmentandcountryside/2018/180424-20m-air-quality-fund-amongnew-measures-to-improve-air-quality-in-wales/?lang=en (accessed on 1 September 2018).

47. Mayor, TfL and the Met Launch Plan to Eliminate Deaths and Serious Injuries on London's Roads. Available online: https://fl.gov.uk/info-for/media/press-releases/2018/july/mayor-tfl-and-the-met-launch-plan-toeliminate-deaths-and-serious-injuries-on-london-s-roa (accessed on 20 August 2018).

48. The Polluting Effect of Wear and Tear in Brakes and Tyres. Available online: https://www.theguardian.com/ environment/2016/sep/11/polluting-effect-wear-brakes-tyres-pollutionwatch (accessed on 1 September 2018).

49. Dijkema, M.; van der Zee, S.; Brunekreef, B.; van Strien, R. Air quality effects of an urban highway speed limit reduction. Atmos. Environ. 2008, 42, 9098-9105. [CrossRef]

50. Harmsen, R.; van den Hoed, R.; Harmelink, M. Improving the Energy Efficiency of Road Transport: The Case of Eco-Driving in the Netherlands. In Proceedings of the European Council for an Energy Efficient Economy Conference, La Colle sur Loup, France, June 2007.

51. BBC TV Shows Community Actions Can Tackle UK Urban Air Pollution. Available online: http://www.environmenttimes.co.uk/news/item/605-bbc-tv-shows-community-action-tackling-ukurban-air-pollution (accessed on 1 September 2018).

52. CORDIS. CITI-SENSE-Result in Brief: Citizen-Based Air Quality Monitoring. European Commission: Norway, 2017. Available online: https://cordis.europa.eu/project/rcn/106482/brief/en (accessed on 14 September 2018).

53. Beware China's 'Anti-Smog Tower' and Other Plans to Pull Pollution from the Air. Available online: https://theconversation.com/beware-chinas-anti-smog-tower-and-other-plans-to-pull-pollutionfrom-the-air-90596 (accessed on 20 August 2018).

54. A Layer of Sunscreen on the Street Might Fight Smog. Available online: https://theconversation.com/a-layerof-sunscreen-on-the-street-might-fight-smog-16545 (accessed on 9 September 2018).

55. Delhi Tests Water Cannons to Combat Deadly Air Pollution. Available online: https://edition.cnn.com/2017/ 12/22/health/india-new-delhi-water-cannon-pollution-intl/index.html (accessed on 20 September 2018).

56. Jayasooriya, V.; Ng, A.; Muthukumaran, S.; Perera, B. Green infrastructure practices for improvement of urban air quality. Urban For. Urban Green. 2017, 21, 34-47. [CrossRef]

57. Currie, B.; Bass, B. Estimates of air pollution mitigation with green plants and green roofs using the UFORE model. Urban Ecosyst. 2008, 11, 409-422.

58. 6 New Technologies Which Could Improve Urban Air Quality. Available online: https://policyexchange.org. uk/6-new-technologies-which-could-improve-urban-air-quality/ (accessed on 22 June 2018).

59. Hubbard, C.; Anderson, J.; Wallington, T. Ethanol and Air Quality: Influence of Fuel Ethanol Content on Emissions and Fuel Economy of Flexible Fuel Vehicles. Environ. Sci. Technol. 2014, 48, 861-867. [CrossRef] [PubMed]

60. Anderson, L. Ethanol fuel use in Brazil: Air quality impacts. Energy Environ. Sci. 2009, 2, $1015-1037$. [CrossRef]

61. Global EV Outlook 2018: Towards Cross-Modal Electrification. Available online: https://webstore.iea.org/ global-ev-outlook-2018 (accessed on 10 September 2018).

62. Overview on Tax Incentives for Electric Vehicles in the EU. Available online: https://www.acea.be/uploads/ publications/EV_incentives_overview_2018.pdf (accessed on 30 September 2018).

63. How Can UK Cities Clean up the Air We Breathe? Lessons from Cities Taking Action to Reduce Roadside Emissions. Available online: http://www.centreforcities.org/wp-content/uploads/2018/01/18-01-12-HowCan-Cities-Clean-up-the-Air-We-Breathe.pdf?platform=hootsuite (accessed on 8 August 2018).

64. German Court Delays Ruling on City Bans for Heavily Polluting Diesel Cars. Available online: https://www.theguardian.com/world/2018/feb/22/german-court-to-rule-on-city-bans-for-heavilypolluting-diesel-cars (accessed on 8 September 2018). 
65. Li, N.; Chen, J.; Tsai, I.; He, Q.; Chi, S.; Lin, Y.; Fu, T. Potential impacts of electric vehicles on air quality in Taiwan. Sci. Total Environ. 2016, 566, 919-928. [CrossRef]

66. Transport Statistics Great Britain 2017. Available online: https://assets.publishing.service.gov.uk/government/ uploads/system/uploads/attachment_data/file/664323/tsgb-2017-print-ready-version.pdf (accessed on 15 September 2018).

67. Brantley, H.; Hagler, G.; Deshmukh, P.; Baldauf, R. Field assessment of the effects of roadside vegetation on near-road black carbon and particulate matter. Sci. Total Environ. 2014, 468-469, 120-129. [CrossRef] [PubMed]

68. Tong, Z.; Baldauf, R.; Isakov, V.; Deshmukh, P.; Max Zhang, K. Roadside vegetation barrier designs to mitigate bear-road air pollution impacts. Sci. Total Environ. 2016, 541, 920-927. [CrossRef]

69. Abhijith, K.; Kumar, P.; Gallagher, J.; McNabola, A.; Baldauf, R.; Pilla, F.; Broderick, B.; Di Sabatino, S.; Pulvirenti, B. Air pollution abatement performances of green infrastructure in open road and built-up street canyon environments-A review. Atmos. Environ. 2017, 162, 71-86. [CrossRef]

70. Do Trees Reduce Air Pollution Levels? Available online: http://www.sciencefocus.com/article/planet-earth/ do-trees-reduce-air-pollution-levels (accessed on 3 July 2018).

71. Morani, A.; Nowak, D.; Hirabayashi, S.; Calfapietra, C. How to select the best tree planting locations to enhance air pollution removal in the MillionTreesNYC initative. Environ. Pollut. 2011, 159, 1040-1047. [CrossRef] [PubMed]

72. Yang, J.; Chang, Y.; Yan, P. Ranking the suitability of common urban tree species for controlling PM2.5 pollution. Atmos. Pollut. Res. 2015, 6, 267-277. [CrossRef]

73. Vos, P.E.J.; Maiheu, B.; Vankerkom, J.; Janssen, S. Improving local air quality in cities: To tree or not to tree? Environ. Pollut. 2013, 183, 113-122. [CrossRef]

74. Pugh, T.; MacKenzie, A.; Whyatt, J.; Hewitt, C. Effectiveness of Green Infrastructure for Improvement of Air Quality in Urban Street Canyons. Environ. Sci. Technol. 2012, 46, 7692-7699. [CrossRef]

75. Planted Buildings: Is This the Future of Our Cities or Just an Eco-Fantasy? Available online: https://www. telegraph.co.uk/gardening/gardens-to-visit/planted-buildings-future-cities-just-eco-fantasy/ (accessed on 15 September 2018).

76. Zupancic, T.; Westmacott, C.; Bulthuis, M. The Impact of Green Space on Heat and Air Pollution in Urban Communities: A Meta-Narrative Systematic Review; David Suzuki Foundation: Vancouver, BC, Canada, 2016.

77. Craig, L.; Krewski, D.; Samet, J.; Shortreed, J.; van Bree, L.; Krupnick, A. International Perspectives on Air Quality: Risk Management Principles for Policy Development. Conference Statement. J. Toxicol. Environ. Health 2008, 71, 4-8. [CrossRef] [PubMed]

78. China's Surprising Solutions to Clear Killer Air. Available online: https://news.nationalgeographic.com/ 2017/05/china-air-pollution-solutions-environment-tangshan/ (accessed on 15 September 2018).

79. Dutta, J.; Chowdhury, C.; Roy, S.; Middya, A.; Gazi, F. Towards Smart City: Sensing Air Quality in City based on Opportunistic Crown-Sensing. In Proceedings of the 18th International Conference on Distributed Computing and Networking, Hyderabad, India, 5-7 January 2017.

80. Annual Estimates of the Resident Population for Incorporated Places of 50,000 or More, Ranked by July 1, 2017 Population. Available online: https:/factfinder.census.gov/faces/tableservices/jsf/pages/productview. xhtml?src=bkmk (accessed on 15 September 2018).

81. All Four Hawaii Counties Formally Join Drive Electric Hawaii. Hawaiian Electric. Available online: https://www.hawaiianelectric.com/all-four-hawaii-counties-formally-join-drive-electric-hawaii (accessed on 10 September 2018).

82. Office of Transportation and Air Quality. Compilation of State, County, and Local Anti-Idling Regulations. Available online: https:/www.epa.gov/sites/production/files/documents/ CompilationofStateIdlingRegulations.pdf (accessed on 10 September 2018).

83. Department of Transportation Services. Public Transit. Available online: http://www.honolulu.gov/dts/ aboutus/publictransit.html (accessed on 10 September 2018).

84. Department of Transportation Services. O'ahu Bike Plan. Available online: https://www.honolulu.gov/ bicycle/bikeplanupdate.html (accessed on 10 September 2018).

85. Honolulu's First Bike-Sharing Program Brings 1000 Bikes to the Streets June 28. Available online: http://www.honolulumagazine.com/Honolulu-Magazine/June-2017/Honolulus-First-Bike-SharingProgram-Brings-1000-Bikes-to-the-Streets-June-28/ (accessed on 10 September 2018). 
86. American Petroleum Institute. State Motor Fuel Taxes. Available online: https://www.api.org/ \{\}/media/ Files/Statistics/StateMotorFuel-OnePagers-July-18.pdf (accessed on 10 September 2018).

87. U.S. Department of Energy. Alternative Fuels Data Centre: Glossary. Available online: https://www.afdc. energy.gov/glossary.html (accessed on 10 September 2018).

88. International Energy Agency. Energy Prices and Taxes: Second Quarter 2018. Available online: https: //www.oecd-ilibrary.org/energy/energy-prices-and-taxes_16096835 (accessed on 10 September 2018).

89. Hawaii State Energy Office. State and Federal Laws \& Incentives. 2018. Available online: http://energy. hawaii.gov/testbeds-initiatives/ev-ready-program/laws-incentives (accessed on 27 August 2018).

90. EV Market Share by State. Available online: http://evadoption.com/ev-market-share/ev-market-share-state/ (accessed on 15 September 2018).

91. Number of Tallinn Residents. Available online: https://www.tallinn.ee/est/Tallinna-elanike-arv (accessed on 2 September 2018).

92. European Commission. Urban Access Regulations in Europe. Available online: http://urbanaccessregulations. eu/ (accessed on 9 September 2018).

93. Republic of Estonia Road Administration. Speed Limits in Estonia. Available online: https://www.mnt.ee/ eng/speed-limits-estonia (accessed on 10 September 2018).

94. The Tallin Experiment: What Happens When a City Makes Public Transport Free? Available online: https: //www.theguardian.com/cities/2016/oct/11/tallinn-experiment-estonia-public-transport-free-cities (accessed on 10 September 2018).

95. Cats, O.; Susilo, Y.; Reimal, T. The prospects of fare-free public transport: Evidence from Tallinn. Transportation 2016, 44, 1083-1104. [CrossRef]

96. World Economic Forum. Estonia Is Making Public Transport Free. Available online: https://www.weforum. org/agenda/2018/06/estonia-is-making-public-transport-free/ (accessed on 15 September 2018).

97. National Center for Transportation Research. Advantages and Disadvantages of Fare-Free Transit Policy. Available online: http://www.fdot.gov/research/Completed_Proj/Summary_PTO/FDOT_BC137_38_FF_rpt. pdf (accessed on 9 September 2018).

98. Sixt Bicycle Rental Locations in Tallinn. Available online: https://www.sixtbicycle.ee/en/Bicycle_rental (accessed on 9 September 2018).

99. Republic of Estonia Tax and Customs Board. Rates of Excise Duty. Available online: https://www.emta. ee/eng/business-client/excise-duties-assets-gambling/about-excise-duties/rates-excise-duty (accessed on 9 September 2018).

100. Santos, G. Road Fuel Taxes in Europe: Do They Internalise Road Transport Externalities? Transp. Policy 2017, 53, 120-134. [CrossRef]

101. Santos, G.; Davies, H. Incentives for quick penetration of electric vehicles in five European countries: Perceptions from experts and stakeholders. Transp. Res. Part A Policy Pract. 2019. [CrossRef]

102. Thiel, C.; Krause, J.; Dilara, P. JRC Science and Policy Report: Electric Vehicles in the EU from 2010 to 2014 Is Full Scale Commercialisation Near? European Commission, Joint Research Centre: Ispra, Italy, 2015.

103. Interactive Map: Correlation between Uptake of Electric Cars and GDP in the EU. Available online: https://www.acea.be/statistics/article/interactive-map-correlation-between-uptake-of-electric-carsand-gdp-in-EU (accessed on 9 September 2018).

104. How Estonia Persuaded Drivers to Go Electric. Available online: https:/elpais.com/elpais/2017/05/29/ inenglish/1496070465_626777.html (accessed on 9 September 2018).

105. The Air Quality Strategy for England, Scotland, Wales and Northern Ireland. Available online: https://assets.publishing.service.gov.uk/government/uploads/system/uploads/attachment_data/file/ 69336/pb12654-air-quality-strategy-vol1-070712.pdf (accessed on 15 September 2018).

106. Air Quality Management Areas: City of Edinburgh Council. Available online: http://www.scottishairquality. co.uk/laqm/aqma?id=370 (accessed on 15 September 2018).

107. National Records of Scotland. Population Estimates for Settlements and Localities in Scotland, Mid-2016. Available online: https://www.nrscotland.gov.uk/files//statistics/settlements-localities/set-loc-16/set-loc-2016publication-updated.pdf (accessed on 9 September 2018).

108. Cleaner Air for Scotland (CAFS) Strategy. Available online: http://www.scottishairquality.co.uk/lez/ (accessed on 9 September 2018). 
109. Scotland to 'Phase out' New Petrol and Diesel Cars by 2032. Available online: https: //www.independent.co.uk/news/uk/politics/scotland-petrol-diesel-cars-phase-out-ban-2032-nicolasturgeon-snp-environment-air-pollution-a7930781.html (accessed on 15 September 2018).

110. About $20 \mathrm{mph}$ for Edinburgh. Available online: http://www.edinburgh.gov.uk/info/20243/20mph_for_ edinburgh/1024/about_20mph_for_edinburgh/1 (accessed on 15 September 2018).

111. Air Quality: Action Plan Revised 2008. Available online: www.edinburgh.gov.uk/download/downloads/id/ 321/air_quality_action_plan (accessed on 9 September 2018).

112. Our Trams. Available online: http://edinburghtrams.com/about-trams/our-trams (accessed on 15 September 2018).

113. The City of Edinburgh Council. Public Transport. Available online: http://edinburgh.cdmf.info/public/bus/ list.htm (accessed on 9 September 2018).

114. $£ 12 \mathrm{~m}$ Dedicated Cycling Network to Be Installed in Edinburgh. Available online: https://www.edinburghnews. scotsman.com/news/12m-dedicated-cycling-network-to-be-installed-in-edinburgh-1-4563673 (accessed on 9 September 2018).

115. The Scotsman. Edinburgh Cycle Hire Scheme Launch Delayed Until Autumn. Available online: https://www.scotsman.com/news/transport/edinburgh-cycle-hire-scheme-launch-delayed-untilautumn-1-4741381 (accessed on 15 September 2018).

116. Growing Take up of Scottish Government Electric Vehicle Finance Scheme. Available online: https://www.scotsman.com/news/environment/growing-take-up-of-scottish-government-electricvehicle-finance-scheme-1-4721864 (accessed on 9 September 2018).

(C) 2019 by the authors. Licensee MDPI, Basel, Switzerland. This article is an open access article distributed under the terms and conditions of the Creative Commons Attribution (CC BY) license (http://creativecommons.org/licenses/by/4.0/). 